


A Journal of Agricultural Science Published by the California Agricultural Experiment Station

\title{
CONTENTS
}

LOCATION OF CURLYTOP VIRUS IN THE BEET LEAFHOPPER, EUTETTIX TENELLUS HENRY H. P. SEVERIN

\section{SPINACH YELLOW DWARF}

HENRY H. P. SEVERIN and DONALD H. LITTLE

\section{WEEDS EXPERIMENTALLY INFECTED WITH BEET-MOSAIC VIRUS}

HENRY H. P. SEVERIN and ROGER M. DRAKE 


\section{CONTENTS}

\section{LOCATION OF CURLY-TOP VIRUS IN THE}

BEET LEAFHOPPER, EUTETTIX TENELLUS ....... 545

Introduction $\ldots \ldots \ldots \ldots \ldots \ldots \ldots \ldots \ldots \ldots \ldots \ldots \ldots \ldots \ldots \ldots \ldots$

Methods ................................ 547

Location of virus in beet leafhopper . . . . . . . . . . 548

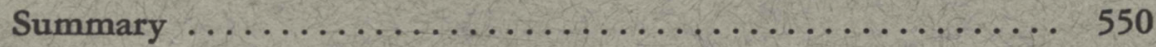

Literature cited $\ldots \ldots \ldots \ldots \ldots \ldots \ldots \ldots \ldots \ldots \ldots \ldots \ldots \ldots \ldots$

SPINACH YELLOW DWARF $\ldots \ldots \ldots \ldots \ldots \ldots \ldots \ldots \ldots, 555$

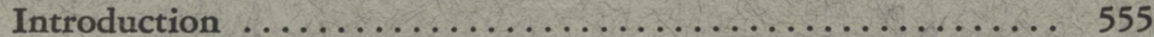

Materials and methods ....................... 555

Symptomatology $\ldots \ldots \ldots \ldots \ldots \ldots \ldots \ldots \ldots \ldots \ldots \ldots ., 556$

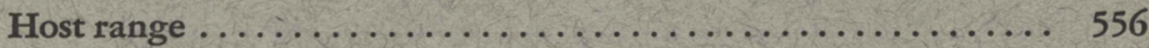

Properties of the virus $\ldots \ldots \ldots \ldots \ldots \ldots \ldots \ldots \ldots \ldots \ldots \ldots \ldots \ldots$

Aphid transmission of the virus . . . . . . . . . . . . . 559

Description of spinach-yellow-dwarf virus . ........... 560

Summary $\ldots \ldots \ldots \ldots \ldots \ldots \ldots \ldots \ldots \ldots \ldots \ldots \ldots \ldots \ldots \ldots$

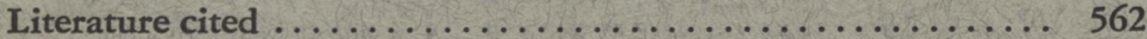

Plates ............................... 563

WEEDS EXPERIMENTALLY INFECTED

WITH BEET-MOSAIC VIRUS ................. 569



Weed host range and symptomatology ............... 569

Nonsusceptible weeds $\ldots \ldots \ldots \ldots \ldots \ldots \ldots \ldots \ldots \ldots \ldots \ldots, 570$

Summary $\ldots \ldots \ldots \ldots \ldots \ldots \ldots \ldots \ldots \ldots \ldots \ldots \ldots . \ldots \ldots \ldots \ldots$

Literature cited ........................... 572

Plates .................................. 573 


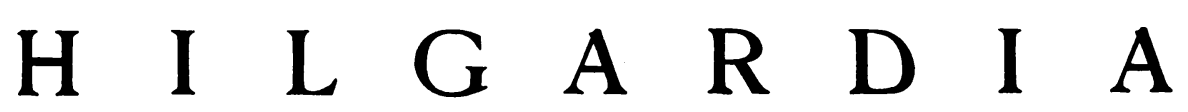

A Journal of Agricultural Science Published by

the California Agricultural Experiment Station

\begin{tabular}{lll}
\hline VoL. 17 & OCTOBER, 1947 & No. 17 \\
\hline
\end{tabular}

\title{
LOCATION OF CURLY-TOP VIRUS IN THE BEET LEAFHOPPER, EUTETTIX TENELLUS ${ }^{1}$
}

\author{
HENRY H. P. SEVERIN ${ }^{2}$
}

\section{INTRODUCTION}

THE CURLY-TOP VIRUS is sometimes transmitted by the beet leafhopper, Eutettix tenellus (Baker), many days after the insect has had an opportunity to acquire the virus by feeding on an infected plant. The retention period of the virus in the insect has been reported to be as long as 151 to 180 days (Freitag, 1936). ${ }^{3}$ The question of where the virus is during this time has interested a number of investigators.

Earlier attempts to determine the location of the virus in the leafhopper were failures. In experiments at this station (Severin, 1922), not a single case of curly top was obtained by inoculating healthy beets with various internal organs from infective beet leafhoppers dissected in physiological salt, Ringer's and Locke's solutions, and in juice expressed from healthy beets. The excrement from infective beet leafhoppers inoculated into the petioles of healthy beets also failed to produce curly top. Carsner and Stahl (1924) dipped the points of steel needles into drops of fresh excreta from infective beet leafhoppers and then pricked the excrement into two beet seedlings, but no disease resulted.

Later, however, Carter (1928a, $b$ ) succeeded in demonstrating curly-top virus in leafhopper saliva. He transmitted the virus by previously noninfective leafhoppers which had fed on a solution on which infective insects had previously fed, the incubation period of the disease in the beets in these instances being, as a rule, prolonged. An attempt (Severin, 1931) to demonstrate its presence in feces by a similar technique was unsuccessful : previously noninfective nymphs after feeding on a feeding solution containing the feces from infective beet leafhoppers failed to transmit curly top to sugar beets. But in 1938 Bennett and Wallace reported that a small amount of virus passes through the beet leafhopper and was present in active condition in

\footnotetext{
${ }^{1}$ Received for publication December 27, 1945.

2 Entomologist in the Experiment Station.

"See "Literature Cited" for citations, referred to in the text by author and date.
} 


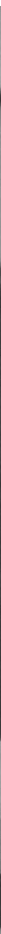

Fig. 1. Apparatus for drop method of feeding noninfective beet leafhopper nymphs on virus extract from internal organs. A drop of virus extract was placed on the "fishskin" covering the flared surface of the glass cage (see also fig. 2). The membrane with a drop of virus extract was placed over the depression of a microculture slide containing a small quantity of water. The feeding apparatus was placed on a glass plate above an electric incandescent lamp to attract the nymphs to the lighted membrane in the glass cage, and the top of the cages was covered with black sateen.

the feces. They also reported that virus was obtained from the blood, salivary glands, and alimentary canal of the beet leafhopper and concluded that the blood is the chief reservoir of the virus.

Dobroscky (1929) in her study on the aster-yellows virus in its insect vector, Macrosteles divisus (Uhler), suggested that "if certain portions of viruscarrying individuals were isolated and healthy insects made to feed on them, one might get an indication of the whereabouts of the virus."

This paper reports the results of further experiments to determine the location of the virus in the beet leafhopper. Attempts were made to determine whether the virus was located in the alimentary canal, salivary glands, saliva, blood, and ovaries of infective beet leafhoppers. Noninfective leafhoppers were fed on filtered solutions in which internal organs of infective insects had been crushed. Investigations were also undertaken on the filterability of the curly-top virus in the various internal organs of infective leafhoppers. 


\section{METHODS}

Feeding Solution. A large number of experiments were conducted with various feeding solutions using different kinds and percentages of sugar. The solutions used were juices from the leaves, petioles, leaves and petioles, beet root, or the entire beet plant, often mixed with various amounts of different sugar solutions.

In our early work the filtrates prepared from the internal organs of infective beet leafhoopers were often incubated, sometimes for a period of

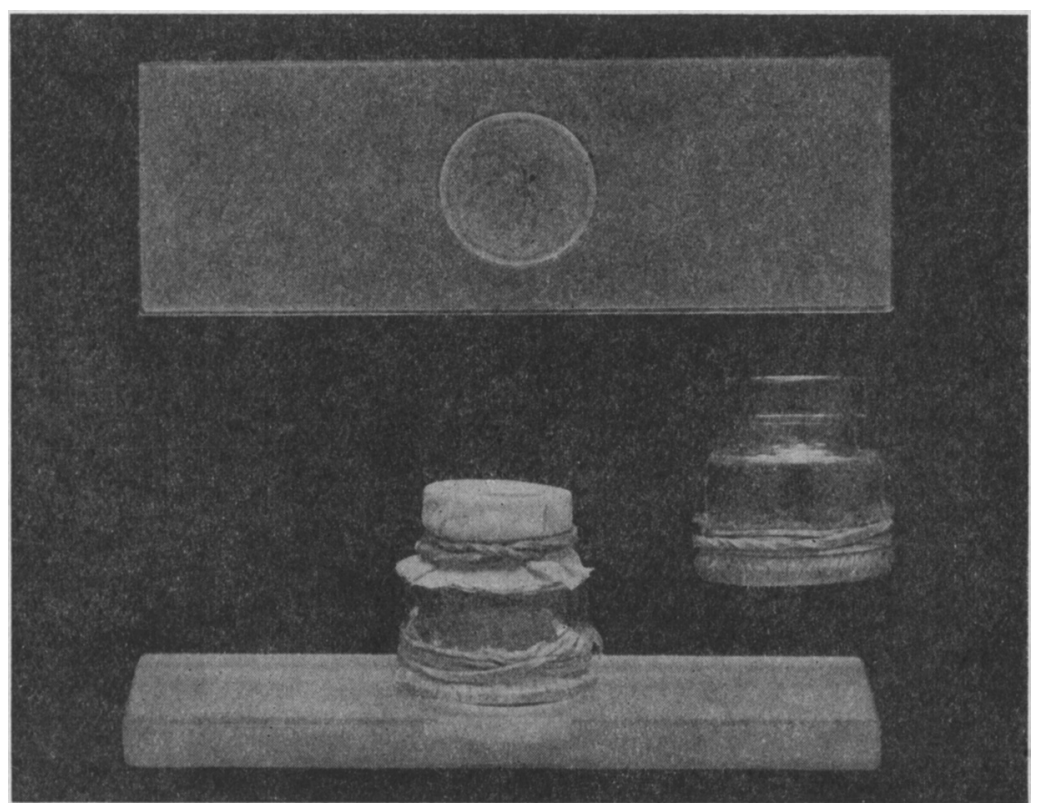

Fig. 2. Microculture slide and glass cage used in feeding noninfective nymphs (shown on glass plate in fig. 1 ).

1 to 7 days. It is not necessary to enter into a discussion of these experiments, which usually gave negative results, since many other experiments have demonstrated that the curly-top virus is inactivated by prolonged incubation of aerobic filtrates.

In our later work the feeding solution mostly used was as follows :

$6 \mathrm{cc}$ filtered healthy beet-root juice

1 cc soluble starch 2 per cent

$1 \mathrm{cc}$ beet sugar 2 per cent

Stahl and Carsner (1918) were the first to report a method of obtaining beet leafhoppers noninfective as to curly top. During the process of hatching from a diseased beet, the nymphs before feeding were transferred with a camel's-hair brush to a healthy beet, and the leafhoppers failed to produce the disease. Successive generations have been reared on healthy beets during 
a period of thirty years, and the leafhoppers remained noninfective throughout this period.

Dissections. Before dissecting out the internal organs from infective beet leafhoppers, the insects were transferred from diseased beets to an empty cage and were kept without food overnight. This was done to avoid the possible transmission of unchanged diseased beet juice in the alimentary canal. The adults were dropped into a small phial containing sterile distilled water, and the bottle was shaken so that the wings became wet and they were unable to fly. The leafhoppers were transferred to fresh distilled water in a Syracuse watch glass with the bottom covered with a mixture of paraffin and beeswax. While the insect was submerged in the distilled water the internal organs were dissected from the adults with a small triangular or spear-shaped scalpel. The internal organs were thoroughly washed with many changes of sterile, distilled water by agitating the liquid with a medicine dropper. The internal organs were transferred to the feeding solution and were crushed with a small pestle in a watch glass.

Filtration. The feeding solution was filtered through coarse and fine Berkefeld candles. Except as otherwise noted, after the internal organs were crushed in the solution each solution was again filtered through a small fine Berkefeld candle.

Feeding Leafhoppers on Virus Extracts. Carter (1927, 1928a) perfected methods of feeding nymphs and adult beet leafhoppers on liquids. Using this feeding apparatus in a modified form, Severin and Swezy (1928) demonstrated, from both diseased sugar beets and crushed infective beet leafhoppers, the filterability of the curly-top virus. These feeding equipments required a considerable amount of liquid and it was assumed that the dilution magnitude of the curly-top virus would play an important role in this work. Hence a feeding technique was devised in which a small quantity of solution was employed in a microculture slide as described in a previous paper (Severin and Swezy, 1928). In some of the experiments noninfective nymphs were fed on a drop of solution placed on the "fishskin" covering the flared surface of a glass cage. The membrane with the drop of liquid was placed over the depression of a microculture slide containing a small quantity of water to prevent evaporation. The feeding apparatus was placed on a glass plate above an electric incandescent lamp (figs. 1 and 2) and the top of the glass cages was covered with black sateen. The nymphs, which had been fasted for a few hours, were attracted to the lighted membrane and soon fed on the drop of solution.

\section{LOCATION OF VIRUS IN BEET LEAFHOPPER}

Midintestine, or Stomach. Experiments were performed to determine whether the curly-top virus was located in the midintestine, or stomach, of infective beet leafhoppers. The fore and hind intestine were torn from the alimentary canal in the dissections and the midintestine left intact. The number of stomachs per cubic centimeter of solution usually varied from 10 to 25 , but sometimes as many as 60 were used. The crushed stomachs in the solution were either fed directly to previously noninfective nymphs or after filtering through a fine Berkefeld candle. The results of inoculating healthy 
sugar-beet seedlings with curly-top virus by previously noninfective nymphs fed on solution containing crushed midintestines from infective adults was as follows :

\begin{tabular}{|c|c|c|}
\hline Unfiltered s & $\begin{array}{c}\text { Beets inoculated } \\
204\end{array}$ & $\begin{array}{c}\text { Beets infected } \\
8\end{array}$ \\
\hline tion & 240 & 9 \\
\hline
\end{tabular}

Salivary Glands. A large number of experiments were conducted with different feeding solutions containing crushed salivary glands dissected from infective beet leafhoppers to determine whether the curly-top virus was located in these organs. In dissecting the adults, the head was severed from the thorax in sterile distilled water. If the heads were allowed to remain in the water for a few minutes the salivary glands protruded from the opening and could easily be dissected out with a small triangular scalpel. The number of salivary glands per cubic centimeter of solution varied from 15 to 25 . Healthy sugar-beet seedlings were inoculated with curly-top virus by means of previously noninfective nymphs fed on unfiltered solutions containing these crushed salivary glands. Of the 352 beets thus inoculated, 39 developed curly-top.

\section{TABLE 1}

Results of Inoculating Healthy Sugar-Beet Seedlings with Previously Noninfective Beet Leafhoppers Fed on Feeding Solutions into Which Infective Leafhoppers Had InJECTEd SALIVA

\begin{tabular}{|c|c|c|c|c|}
\hline Feeding solution & $\begin{array}{l}\text { Infective } \\
\text { nymphs fed } \\
\text { feeding } \\
\text { solution }\end{array}$ & $\begin{array}{c}\text { Beets } \\
\text { inoculated }\end{array}$ & $\begin{array}{c}\text { Beets } \\
\text { infected }\end{array}$ & $\begin{array}{c}\text { Incubation } \\
\text { period } \\
\text { of disease } \\
\text { in plant }\end{array}$ \\
\hline & number & number & number & days \\
\hline $\begin{array}{l}8 \text { cc steam-extracted beet-root juice plus } 8 \text { ce } 5 \text { per cent } \\
\text { beet-sugar solution } \ldots \ldots \ldots \ldots \ldots \ldots \ldots \ldots \ldots \ldots \ldots \ldots \ldots \ldots\end{array}$ & $200-500$ & 40 & 3 & $12,13,16$ \\
\hline 16 cc healthy beet-root juice $\ldots \ldots \ldots \ldots \ldots \ldots \ldots \ldots$ & $200-500$ & 18 & 7 & $\begin{array}{l}9,12,13,14 \\
14,14,36\end{array}$ \\
\hline 16 cc filtered healthy beet-root juice... & $200-500$ & 18 & 0 & $\ldots \ldots$ \\
\hline
\end{tabular}

Saliva. Experiments on the transmission of curly-top virus by previously noninfective beet leafhoppers which had fed on solutions in which saliva was injected by infective leafhoppers were made with three feeding solutions. The feeding equipment consisted of a small culture or "Esmarch" dish $(50 \times 10 \mathrm{~mm})$ containing about $16 \mathrm{cc}$ of solution (fig. 3) as described in a previous paper (Severin and Swezy, 1928). The results are indicated in table 1.

As in Carter's experiments, previously mentioned (p. 545), the incubation period of the disease in the beet was occasionally prolonged: in one beet it was 36 days, as compared with the usual period of 10 to 14 days under greenhouse conditions.

Blood. Attempts were made to determine whether the curly-top virus was located in the blood of infective beet leafhoppers. The aorta opens in the vicinity of the brain. Hence the leafhoppers were decapitated, and the blood was allowed to ooze into a drop of the culture medium. The solution consisted of sterile distilled water containing 5 per cent alcoholic pure sucrose. Blood from 25 infective beet leafhoppers was used for each cubic centimeter of solu- 
[Vol. 17, No. 17

tion. Previously noninfective nymphs were fed on the solution, both unfiltered and filtered, and then transferred to healthy beet seedlings. The results were as follows:

\begin{tabular}{|c|c|c|}
\hline & Beets inoculated & Beets infected \\
\hline Unfiltered solution $\ldots \ldots \ldots \ldots \ldots \ldots$ & 14 & 4 \\
\hline Filtered solution $\ldots \ldots \ldots \ldots$ & 50 & 1 \\
\hline
\end{tabular}

Ovaries. Tests were made to determine whether the curly-top virus could be transmitted with the ovaries crushed in a solution. The blood, which contains the curly-top virus, bathes the ovaries; hence they were thoroughly

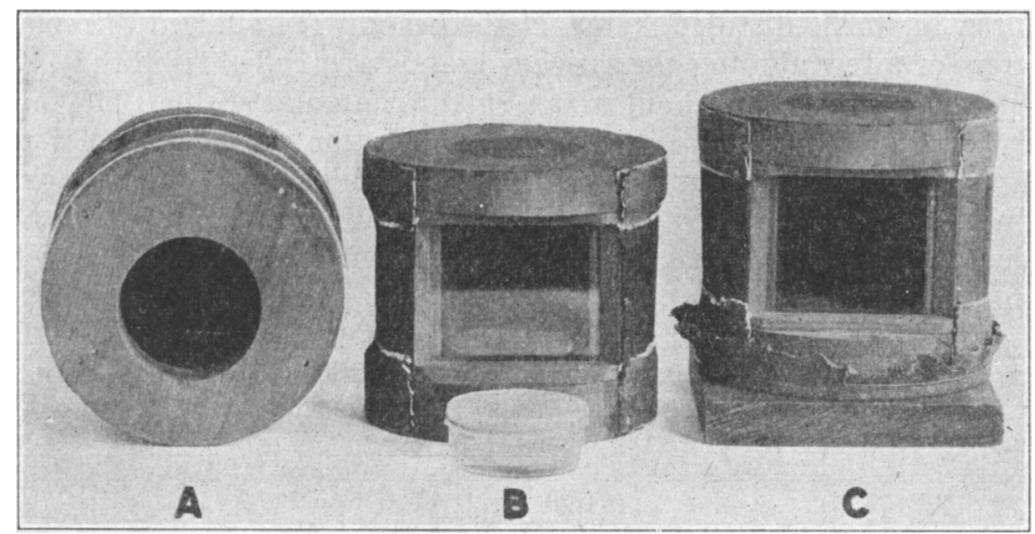

Fig. 3. Small culture or "Esmarch dish" containing feeding solution placed directly behind the glass in a cage lined with black sateen.

washed in many changes of sterile, distilled water. The ovaries from 10 to 50 females were dissected and crushed in 1 cubic centimeter of solution. The microculture slide and drop methods of feeding were used. Previously noninfective nymphs after feeding on the culture solution containing the crushed ovaries failed to transmit curly-top virus to any of 112 beets in 56 feeding experiments.

\section{SUMMARY}

Previously noninfective beet leafhoppers obtained the curly-top virus and transmitted the infective principle to healthy beet seedlings by feeding on solutions containing crushed stomach, salivary glands, saliva, and blood from infective leafhoppers and on the filtrates prepared with these organs. Negative results were obtained with the ovaries dissected from infective female leafhoppers.

The saliva containing the virus was injected into a feeding solution by infective beet leafhoppers and was recovered by previously noninfective insects and transferred to beet seedlings. 


\section{LITERATURE CITED}

BENNETT, C. W., and H. E. WALLACE.

1938. Relation of the curly-top virus to the vector, Eutettix tenellus, Jour. Agr. Res. $56: 31-51$.

CARsner, E., and C. F. Stahl.

1924. Studies on curly-top disease of the sugar beet. Jour. Agr. Res. 28:297-320.

CARTER, W.

1927. A technique for use with homopterous vectors of plant disease, with special reference to the sugar-beet leafhopper, Eutettix tenellus (Baker). Jour. Agr. Res. 34 : 449-51.

1928a. An improvement in the technique for feeding homopterous insects. Phytopathology $18: 246-47$.

1928b. Transmission of the virus of curly-top of sugar beets through different solutions. Phytopathology $18: 675-79$.

DoBRosCKY, I. D.

1929. Is the aster-yellows virus detectable in its insect vector 9 Phytopathology $19: 1009$ 1015.

Freitag, J. H.

1936. Negative evidence on multiplication of curly-top virus in the beet leafhopper, Eutettix tenellus. Hilgardia 10(9) :263-302.

SEVRRIN, H. H. P.

1921. Minimum incubation periods of causative agent of curlyleaf in beet leafhopper and sugar beet. Phytopathology 11:424-29.

1922. Curlyleaf transmission experiments with beet leafhopper. Jour. Econ. Entom. $15: 182$.

1931. Modes of curly-top transmission by the beet leafhopper, Eutettix tenellus (Baker). Hilgardia 6(8):253-76.

Severis, H. H. P., and O. SwEZY.

1928. Filtration experiments of curly top of sugar beets. Phytopathology 18:681-90.

STAHL, C. F., and E. Carsner.

1918. Obtaining beet leafhoppers nonvirulent as to curly-top. Jour. Agr. Res. 14 :393-94. 

